\title{
Article
}

\section{Scrophularia buergeriana Extract (Brainon) Improves Scopolamine-Induced Neuronal Impairment and Cholinergic Dysfunction in Mice through CREB-BDNF Signaling Pathway}

\author{
Hae-Jin Lee ${ }^{1,+}{ }^{,}$Hae-Lim Kim ${ }^{1,+}\left(\mathbb{D}\right.$, Dae-Young Lee ${ }^{2} \mathbb{C}$, Dong-Ryung Lee ${ }^{3}$, Bong-Keun Choi ${ }^{3}$ and \\ Seung-Hwan Yang ${ }^{1, *(D)}$ \\ 1 Department of Biotechnology, Chonnam National University, Yeosu 59626, Korea; \\ haecutejin@naver.com (H.-J.L.); ics1357@naver.com (H.-L.K.) \\ 2 Department of Herbal Crop Research, National Institute of Horticultural and Herbal Science, \\ Rural Development Administration (RDA), Eumseong 27709, Korea; dylee0809@korea.kr \\ 3 Nutrapharm Tech, Jungwon-gu, Seongnam, Gyunggi 13201, Korea; drlee@nutrapharm.co.kr (D.-R.L.); \\ cbcbcbk@nutrapharm.co.kr (B.-K.C.) \\ * Correspondence: ymichigan@jnu.ac.kr; Tel.: +82-61-659-7306 \\ + These authors contributed equally to this work.
}

Citation: Lee, H.-J.; Kim, H.-L.; Lee, D.-Y.; Lee, D.-R.; Choi, B.-K.; Yang, S.-H. Scrophularia buergeriana Extract (Brainon) Improves ScopolamineInduced Neuronal Impairment and Cholinergic Dysfunction in Mice through CREB-BDNF Signaling Pathway. Appl. Sci. 2021, 11, 4286. https://doi.org/10.3390/ app11094286

Academic Editor: Hari

Prasad Devkota

Received: 11 March 2021

Accepted: 7 May 2021

Published: 10 May 2021

Publisher's Note: MDPI stays neutral with regard to jurisdictional claims in published maps and institutional affiliations.

Copyright: (c) 2021 by the authors. Licensee MDPI, Basel, Switzerland. This article is an open access article distributed under the terms and conditions of the Creative Commons Attribution (CC BY) license (https:/ / creativecommons.org/licenses/by/ $4.0 /)$.

\begin{abstract}
We evaluated the effectiveness of Scrophularia buergeriana extract (Brainon) on cognitive dysfunction and determined its underlying mechanisms in a scopolamine (SCO)-treated mouse model of memory impairment. Brainon treatment for 28 days ameliorated the symptoms of memory impairment as indicated by the results of both passive avoidance performance and the Morris water mazes. Brainon lowered acetylcholinesterase activity and raised acetylcholine levels in the hippocampus. The treatment elevated the protein levels of brain-derived neurotrophic factor (BDNF) and phosphorylated cAMP response element-binding (CREB). Additionally, the excessive generation of SCO-induced reactive oxygen species (ROS) and subsequent oxidative stress were suppressed by the enhancement of superoxide dismutase (SOD)-1 and SOD-2 proteins. mRNA levels of upregulated interleukin (IL)-1 $\beta$, IL-6, and tumor necrosis factor (TNF)- $\alpha$, as well as the apoptotic protein Bcl-2-associated X protein (Bax), cleaved caspase-9, and cleaved poly adenosine diphosphateribose polymerase (PARP) expression after SCO injection were downregulated by Brainon treatment. Collectively, these findings suggested that Brainon possesses anti-amnesic effects through the CREBBDNF pathway. Moreover, it exerted antioxidant, anti-inflammatory, and anti-apoptotic effects in SCO-induced mice exhibiting cognitive impairment and memory loss.
\end{abstract}

Keywords: Scrophularia buergeriana; anti-amnesic effect; cholinergic neurotransmission; anti-oxidant; anti-inflammation; anti-apoptotic

\section{Introduction}

The characterization of Alzheimer's diseases (AD) represents amyloid $\beta$ accumulation, hyperphosphorylation of the tau protein, increased inflammation and oxidative stress leading to neuronal death, which is accompanied by an impairment in memory and cognitive abilities [1,2]. Moreover, a decrease in the neurotransmitter, acetylcholine (Ach), in the $\mathrm{AD}$ brain is a crucial factor responsible for dementia [1].

Scopolamine (SCO) is a muscarinic receptor blocker and tropane alkaloid drug that interrupts cholinergic nerve transmission, causing memory disability and cognitive deficits in the central nervous system (CNS) [1,3-6]. Normal cholinergic activity in the CNS influences hippocampal nerve regeneration and memory impairment via the cAMP response elementbinding protein (CREB)-brain-derived neurotrophic factor (BDNF) signaling [7]. SCO administration causes cholinergic neuronal pathway dysregulation, including increased acetylcholinesterase (AChE) activity, suppression of ACh release and impairment of the memory circuit, and decreased CREB-BDNF levels. Moreover, the neuronal inflammatory 
cascade, oxidative stress generation, and neuron cell death, including cholinergic malfunction, are causative factors in patients with neurodegenerative disorders. The hippocampus is susceptible to oxidative stress, and excessive oxidative stress induces memory deficiency by damaging synaptic plasticity and causing inflammation and neuronal cell death $[7,8]$. SCO-treated mice showed oxidative stress-induced neuronal inflammation and apoptosis in the brain [9]. Therefore, SCO injection of animals is utilized as a useful pharmacological experimental model for cognitive degeneration and memory disorders in $\mathrm{AD}$ [2-5].

Scrophularia buergeriana Miquel (SB), belonging to the Scrophulariaceae family, is indigenous to Korea and also found abundantly in China and Japan. In traditional medicine, dried $\mathrm{SB}$ roots have long been used to alleviate high fever, swollen skin, obstipation, pharyngitis, neuro-inflammation, and throat infection [10]. SB roots have been found to contains various components such as E-harpagoside, 8-O-E-p-methoxycinnamoyl harpagide (MCA$\mathrm{Hg}$ ), E-p-methoxy-cinnamic acid (p-MCA), cinnamic acid, and angoroside C. Moreover, we confirmed that Brainon exhibited significant neuroprotective effects against neurotoxicity caused SH-SY5Y cells by glutamate [11]. We previously demonstrated that Brainon exerts anti-amnesic effects via inhibition of amyloid beta accumulation and hyperphosphorylation of tau protein in memory deficit mice by $\beta$-amyloid [12].

Therefore, we administrated 30 or $100 \mathrm{mg} / \mathrm{kg}$ Brainon based on the previous study [12] and confirmed the cognitive-improving activities of Brainon using passive avoidance performance and Morris water maze (MWM) task based on this research. To demonstrate the potential mechanism of Brainon, we confirmed the CREB-BDNF signaling pathway, AChE activity, and ACh levels in mice hippocampal tissue. Moreover, the anti-inflammatory and antioxidant effects of Brainon, as well as its effects on neuronal death, were evaluated in SCO-caused memory-impaired mice.

\section{Materials and Methods}

\subsection{Preparation of Sample}

Brainon was supplied by Nutrapharm Tech Co., Ltd., (Seongnam, Korea). SB roots were dried and extracted using $70 \% \mathrm{EtOH}$. The resulting solution was filtered, concentrated, and dried to yield Brainon extract (SB extract; $\mathrm{SBE}$ ). The detailed process has been described previously [11,12]. To dissolve the Brainon, we used $0.5 \%$ carboxy-methylcellulose (CMC) and then applied for the in vivo study.

\subsection{Animals}

The experimental protocol and process were admitted by the Animal Care and Use Committee (Permission number: 2019-05-003) of ChemOn Inc. (YoungIn, Korea). Eightweek-old male C57BL/6N mice were offered (Orient Bio, Seongnam, Korea) and housed under regulated conditions (temperature: $23 \pm 3{ }^{\circ} \mathrm{C}$, $12 \mathrm{~h}$ light/dark cycle, $55 \pm 15 \%$ humidity, lighting intensity 150-300 Lux). They freely utilized food and drinking water and had an acclimation period for a week before the experiment started.

\subsection{Design of Experiment}

The experimental mice were randomized into 5 groups after 1-week adaptation $(n=8$ per group): Normal group, SCO-treated group, SCO with Brainon (30 or $100 \mathrm{mg} / \mathrm{kg} /$ day). Ginkgo Biloba Extract (GBE, $50 \mathrm{mg} / \mathrm{kg} /$ day), which was found to have an improving effect on memory deficit $[13,14]$, was used as a positive control agent. $0.5 \% \mathrm{CMC}$ was used to dissolve Brainon and GBE and administered $(10 \mathrm{~mL} / \mathrm{kg} /$ day $)$ for 28 days via gastric gavage. The passive avoidance test was performed for 3 days (days 15-17), whereas the MWM task was performed for 7 days (days 22-28). Memory deficiency was caused by SCO injection ( $1 \mathrm{mg} / \mathrm{kg}$, i.p.) within $30 \mathrm{~min}$ following the oral administration of Brainon and GBE extract. Behavior test was conducted for $30 \mathrm{~min}$ after the SCO injection. 


\subsection{Step-Through Passive Avoidance Performance}

The device (Twin County Med Associates, Hudson, NY, USA) for the passive avoidance test consisted of two identical compartments, separated into light and dark areas with an automated door and electric floor. Experiments were conducted at the same time every day for 3 days. The mice were placed in the dark compartments for $120 \mathrm{~s}$ before being moved back to the lit compartments. If the mice moved to a dark area, they were immediately transferred back to the lit compartment (day 15). During the acquisition trial (day 16), mice could move freely without lighting for $60 \mathrm{~s}$ for familiarization. After adaptation training, they were permitted to enter the two compartments and move freely for $120 \mathrm{~s}$ and, when moved to the dark area, a $0.20 \mathrm{~mA}$ scrambled shock was treated. Animals that did not move were removed from the tests. On the retention trial (day 17), the mice were located in the light section and the automated board was opened, and the transfer time to the dark section was analyzed.

\subsection{MWM Trial}

To confirm the long-term spatial memory ability of the mice, an MWM test was conducted from days 22 to 28 . The MWM tasks consisted of a training session for 2 days (days 22 and 23), a behavioral session for the following 5 days (days 24-27), and a probe trial session for 1 day (day 28). Mice were allowed $60 \mathrm{~s}$ to find the hidden platform located at one of the water pool's release points. If the mice could not locate the platform, they were manually located on the platform for $30 \mathrm{~s}$. All mice were tested in two trials per day and the platform location in the water pool was randomly altered between trials. Learning and memory capabilities were confirmed by measuring the escape latency. The platform was eliminated from the pool and probe trials were performed to confirm the spatial memory ability by checking the platform crossing number of the mice for $60 \mathrm{~s}$ at day 28 . Figure 1 is a schematic of the experimental design.

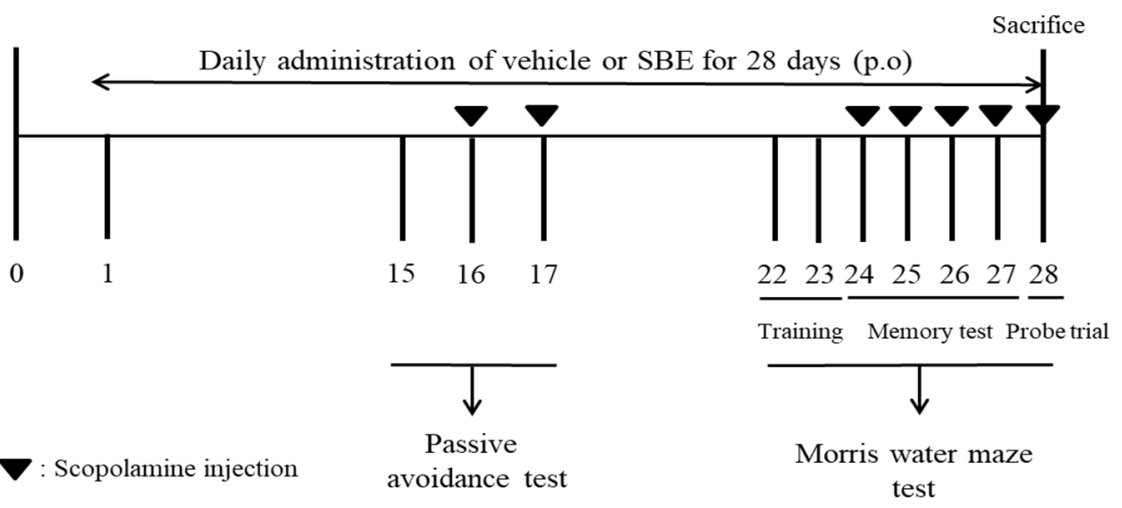

Figure 1. Experiment process of scopolamine-treated memory deficiency in mice.

\subsection{AChE Activity and Contents of ACh}

The hippocampi were homogenized with cold phosphate-buffered saline and centrifuged $(1500 \times g)$ for $15 \mathrm{~min}$ at $4{ }^{\circ} \mathrm{C}$. Centrifuged supernatant was gathered to confirm AChE activity and ACh levels utilizing commercial kits (Abcam, Cambridge, UK), in accordance with the manufacturer's manuals.

\subsection{Preparation of Total $R N A$ and Quantitative RT-PCR}

Mice hippocampi were pulverized, and the total RNA was isolated utilizing a RNeasy Mini kit following the manufacturer's manuals (Qiagen GmbH, Hilden, Germany). cDNA synthesis was carried out utilizing a CellScript ${ }^{\mathrm{TM}}$ All-in-One cDNA Master Mix (CellSafe, Yongin, Korea) at $25^{\circ} \mathrm{C}(5 \mathrm{~min})$ and $42{ }^{\circ} \mathrm{C}(15 \mathrm{~min})$. qPCR was conducted using a QuantStudio 3 Real-time PCR device (Thermo Fisher Scientific Inc., Waltham, MA, USA). The synthesized primers for PCR are shown in Table 1 . Conditions of cycling were $95^{\circ} \mathrm{C}$ (10 min), followed by 50 cycles of $95^{\circ} \mathrm{C}(15 \mathrm{~s})$ and $72{ }^{\circ} \mathrm{C}(60 \mathrm{~s})$. The target gene levels were 
determined by the comparative Ct method utilizing LightCycler 96 Software 1.1 (Roche Diagnostics, Basel, Switzerland).

Table 1. Real-time PCR primer sequences.

\begin{tabular}{ccc}
\hline & Gene & Primer Sequence \\
\hline \multirow{2}{*}{ IL-1 $\beta$} & Forward & 5'-ATG GCA GTT CCT GAA CTC AAC T-3' $^{\prime}$ \\
& Reverse & 5'-CAG GAC AG TAT AGA TTC TTT CCT TT-3' \\
IL-6 & Forward & 5'-GAT GCT ACC AAA CTG GAT ATA ATC-3' \\
& Reverse & $5^{\prime}$-GGT CCT TAG CCA CTC CTT CTG TG-3' \\
TNF- $\alpha$ & Forward & 5'-ATG AGC ACA GAA AGC ATG ATC CGC-3' $^{\prime}$ 5'-CCT CCT TAG CCA CTC CTT CTG TG-3' \\
\multirow{2}{*}{ GAPDH } & Reverse & 5'-CGG TGC TGA GTA TGT CGT GGA GTC T-3' \\
& Forward & 5'-GTT ATT ATG GGG GTC TGG GAT GGA A-3' \\
\hline
\end{tabular}

\subsection{Extraction of Protein and Western Blot Analysis}

The hippocampi were homogenized with RIPA reagent (DYNE Bio, Seongnam, Korea) and the homogenates were centrifuged $(10,000 \times g)$ for $15 \mathrm{~min}$ at $4{ }^{\circ} \mathrm{C}$. Supernatant of hippocampal tissue was harvested, and protein concentrations were quantified utilizing a commercially available BCA protein assay kit (Thermo, Waltham, MA, USA). $30 \mu \mathrm{g}$ of total protein was electrophoresed on SDS-PAGE and moved onto membranes (Millipore Corp., Bedford, MA, USA). For blocking, the membranes were kept for $1 \mathrm{~h}$ at $23^{\circ} \mathrm{C}$ then incubated with the first antibodies for SOD-1, SOD-2, GAPDH (Santa Cruz Biotechnology, Santa Cruz, CA, USA), Bax, Bcl-2, cleaved PARP, cleaved caspase-9, phosphor-CREB, CREB (Cell Signaling Technology, Inc., Danvers, MA, USA), and BDNF (Abcam, Cambridge, UK) at a 1:1000 dilution at $23^{\circ} \mathrm{C}$ for $1 \mathrm{~h}$. The incubated membranes were washed and further reacted with second antibodies (1:1000; GenDEPOT, Barker, TX, USA) at $23^{\circ} \mathrm{C}$ for $1 \mathrm{~h}$. The membranes were processed for detection using ECL solution (Atto, Tokyo, Japan) and the band intensity was measured utilizing Image-Pro Plus (Media Cybernetics, Inc., Rockville, MD, USA).

\subsection{Statistical Analysis}

Statistical analysis between groups was conducted using Student's $t$-test and one-way analysis of variance followed by multiple comparisons Dunnett's post-hoc test utilizing Origin 7.0 (OriginLab, Northhampton, MA, USA). Results are expressed as the means \pm standard error of the mean. Significant differences between groups were considered statistically significant at $p<0.05$ and $p<0.01$.

\section{Results}

\subsection{Composition of Brainon}

The marker compound in Brainon was confirmed by high-performance liquid chromatography (HPLC) analysis. Quantitative analysis of Brainon revealed that Angoroside C content was determined at approximately $0.5 \%$ (Data not shown), and the optimized Brainon was used for the following experiments.

\subsection{Brainon Recovers Scopolamine-Treated Step-through Latency in the Passive Avoidance Test}

To assess the effectiveness of Brainon on learning and fear-motivated memory, we conducted the passive avoidance task. The SCO-injected group had a considerably shorter step-through latency compared with Normal group (Figure 2). However, Brainon 30 and $100 \mathrm{mg} / \mathrm{kg}$ treatment considerably restored $(p<0.05)$ the scopolamine-caused cognitive deficit and GBE $50 \mathrm{mg} / \mathrm{kg}$ administration also improved $(p<0.05)$ memory function when comparison with SCO-injected group only. 


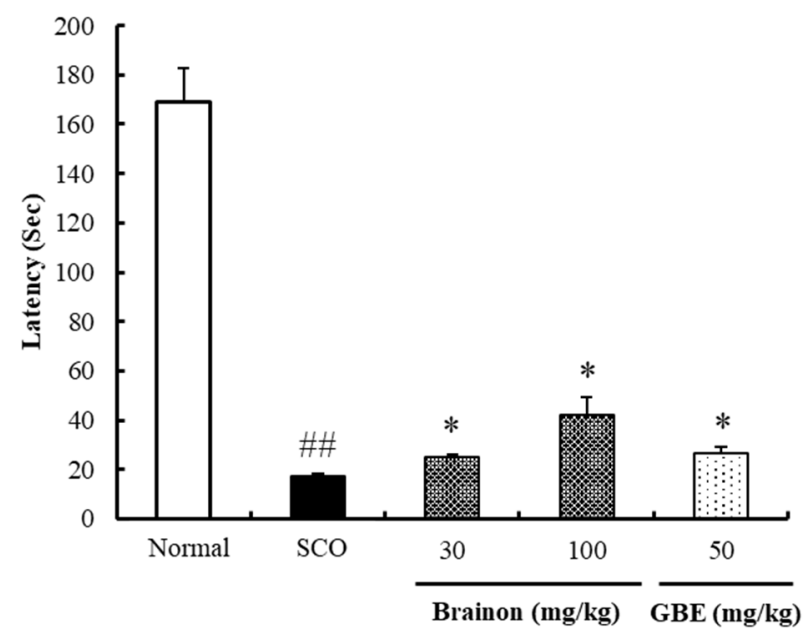

Figure 2. Effects of Brainon scopolamine-treated memory deficit in passive avoidance performance. Values are represented as means $\pm \operatorname{SEM}(n=8)$. \#\# $p<0.01$ vs. Normal group; ${ }^{*} p<0.05$ vs. SCO-treated group.

\subsection{Brainon Improves SCO-Induced Spatial Memory Deficiency in the Morris Water Maze Task}

To examine the effects of Brainon on the spatial memory impairment of mice, escape latency, swim distance, and the platform crossing numbers were assessed in all test groups. Figure 3A revealed that the escape latency of the SCO-treated group was significantly prolonged for 4 days (days 24-27) compared to that in the Normal group $(p<0.01)$. In contrast, $100 \mathrm{mg} / \mathrm{kg}$ Brainon and $50 \mathrm{mg} / \mathrm{kg}$ GBE shortened $(p<0.05)$ the escape latency on days 26 and $27 ; 100 \mathrm{mg} / \mathrm{kg}$ Brainon also decreased $(p<0.05)$ the escape latency compared to that in the SCO-treated group from day 25. Swimming distance to find the platform in the MWM task showed similar results to those of the escape latency (Figure 3B). The mice in the Brainon $30(p<0.05), 100(p<0.01)$, and GBE $50(p<0.05) \mathrm{mg} / \mathrm{kg}$ groups swam shorter distances to locate the platform in comparison with the SCO-treated groups on day 26. We confirmed that the dose of $30 \mathrm{mg} / \mathrm{kg}(p<0.05)$ and $100 \mathrm{mg} / \mathrm{kg}(p<0.05)$ Brainon on day 27 reduced the swimming distance in mice when finding the platform. In the probe trials (Figure 3C) on day 28, the platform crossing numbers of the mice in the SCO-treated group was considerably lower comparison with that of the mice in the Normal group $(p<0.01)$. On the other hand, administration with 30 and $100 \mathrm{mg} / \mathrm{kg}$ of Brainon $(p<0.01)$ and $50 \mathrm{mg} / \mathrm{kg} \mathrm{GBE}(p<0.01)$ increased the platform crossing numbers comparison with that observed in the SCO-injected group. Our results demonstrate that Brainon administration enhanced spatial, learning, and memory functions in SCO-treated memory-deficient mice.

A

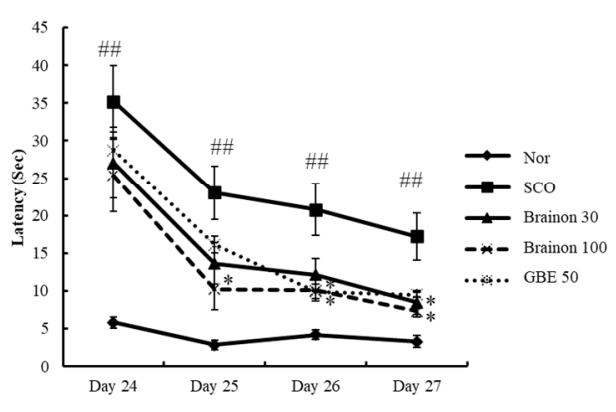

B

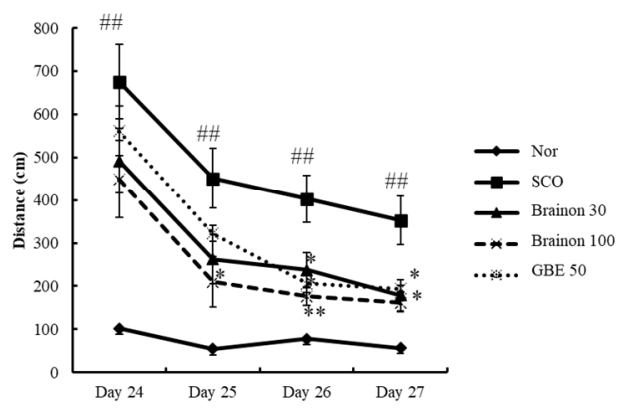

C

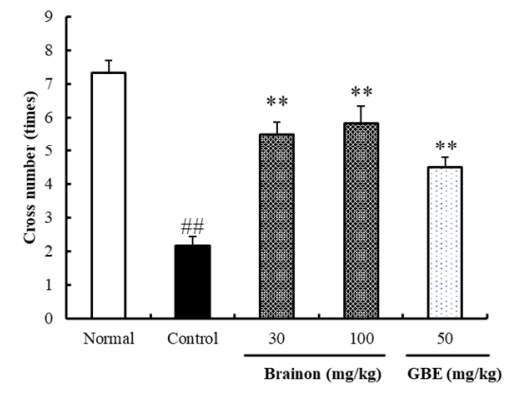

Figure 3. Effects of Brainon scopolamine treated spatial memory deficiency in the MWM trial. (A) The escape latency (s) and (B) swim distance of mice was investigated for 4 days (C) The platform crossing number was carried out on probe trial. Values are represented as means $\pm \operatorname{SEM}(n=8)$. \#\# $p<0.01$ vs. Normal group; ${ }^{*} p<0.05$ and ${ }^{* *} p<0.01$ vs. SCO-treated group. 


\subsection{Brainon Decreases AChE Activity and Increases ACh Levels in SCO-Induced Hippocampal Tissues}

To evaluate the effects of Brainon on AChE and ACh levels, we determined AChE activity and ACh levels in SCO-treated hippocampal tissue. Figure 4A shows that AChE activity in the Normal group was lower than that of the SCO-treated group. Exposure to $100 \mathrm{mg} / \mathrm{kg}$ Brainon $(p<0.01)$ and $50 \mathrm{mg} / \mathrm{kg}$ GBE $(p<0.01)$ considerably lowered $\mathrm{AChE}$ activity comparison with that in the SCO-injected group. However, the ACh levels were found to differ (Figure 4B). SCO treatment significantly downregulated ACh levels in the hippocampus. On the contrary, treatment with $30(p<0.05)$ and $100(p<0.01)$ $\mathrm{mg} / \mathrm{kg}$ Brainon increased ACh levels in a dose dependent comparison with that in the SCO-injected group.

$\mathbf{A}$

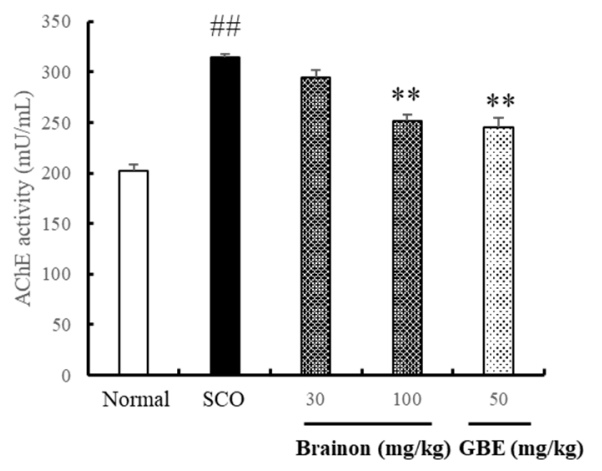

B

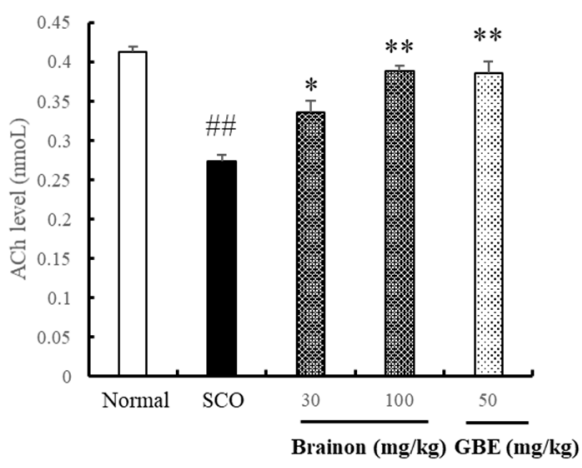

Figure 4. Effects of Brainon on acetylcholinesterase (AChE) activity and acetylcholine (ACh) level in mice hippocampal tissues. The hippocampal tissues were homogenized, and the supernatant was used for calculation of (A) AChE activity and (B) ACh level. Values were calculated in units per mg protein are represented as means $\pm \operatorname{SEM}(n=3)$. \#\# $p<0.01 \mathrm{vs.}$ Normal group; ${ }^{*} p<0.05$ and ${ }^{* *} p<0.01$ vs. SCO-treated group.

\subsection{Brainon Increases BDNF Protein Expression and CREB Phosphorylation Levels in SCO-Induced Hippocampal Tissue}

To demonstrate the effectiveness of Brainon on the memory-associated proteins in SCO-treated cognitive impairment, we measured the BDNF expression and phosphorylated CREB levels using western blotting. Figure 5 shows that SCO treatment significantly decreased the expression of BDNF and phosphorylated CREB in the hippocampus comparison with that in the Normal group $(p<0.01)$. However, in the hippocampus, $100 \mathrm{mg} / \mathrm{kg}$ Brainon $(p<0.01)$ and $50 \mathrm{mg} / \mathrm{kg}$ GBE $(p<0.01)$ prevented a decrease in BDNF protein compared to that in the SCO-treated group. In addition, treatment with $30(p<0.01)$ and $100(p<0.01) \mathrm{mg} / \mathrm{kg}$ of Brainon increased the levels of phosphorylated CREB in a dose dependent comparison to the hippocampal tissue in the SCO-injected group.

\subsection{Brainon Upregulates the Expression of SOD-1 and SOD-2 in SCO-Induced Hippocampal Tissue}

To examine the effects of Brainon on antioxidant enzymes, we determined SOD-1 and SOD-2 levels in SCO-treated hippocampal tissue of mice. SCO treatment significantly decreased SOD-1 and SOD-2 levels in comparison with that in the Normal group. However, administration with $30(p<0.01)$ and $100(p<0.01) \mathrm{mg} / \mathrm{kg}$ Brainon increased SOD-1 levels by 1.6- and 3.6-fold, respectively, whereas administration with $50 \mathrm{mg} / \mathrm{kg}(p<0.01)$ of GBE recovered the decreased SOD-1 levels 3.9-fold with SCO treatment. Furthermore, treatment with $100 \mathrm{mg} / \mathrm{kg}(p<0.01)$ Brainon and $50 \mathrm{mg} / \mathrm{kg}(p<0.01)$ GBE also enhanced SOD-2 levels by 1.9- and 2.1-fold, respectively, in comparison with the mice in the SCO-injected group (Figure 6). 
A

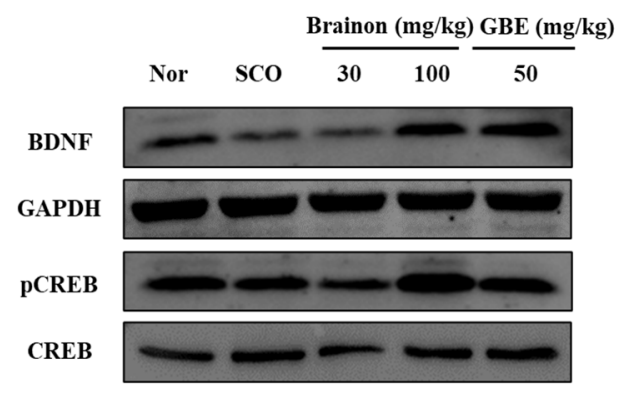

B

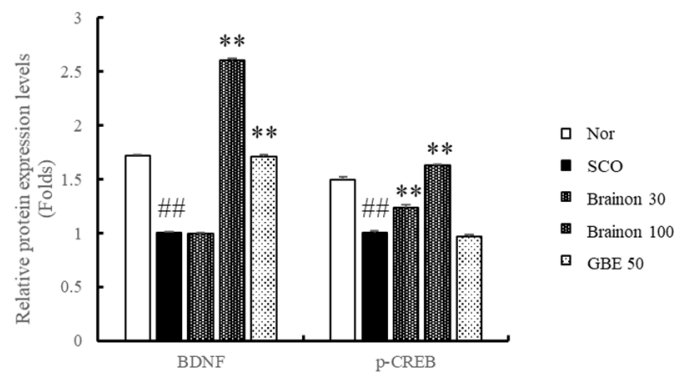

Figure 5. Effects of Brainon on CREB-BDNF pathway in the memory deficit mice hippocampal tissues. (A) Brain-derived neurotrophic factor (BDNF) and phosphorylation of cAMP-response element-binding protein (CREB) was measured via western blotting. (B) The protein band density was determined using the software. Phosphorylation levels of the CREB protein were normalized using the CREB, and BDNF protein was normalized using the GAPDH. Values are expressed as means $\pm \operatorname{SEM}(n=3)$. \#\# $p<0.01$ vs. Normal group; ${ }^{* *} p<0.01$ vs. SCO-treated group.

A

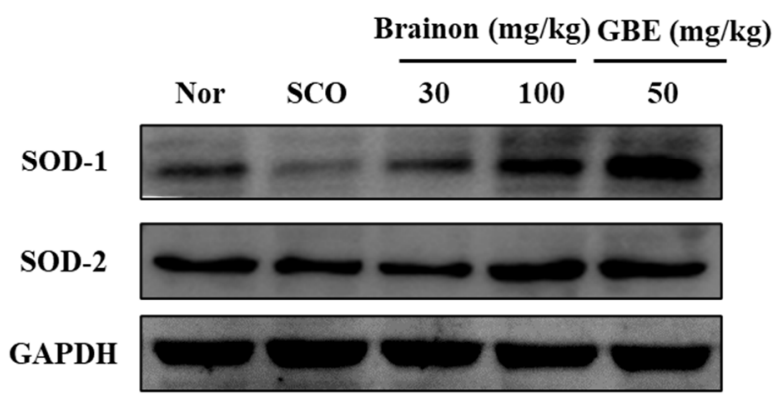

B

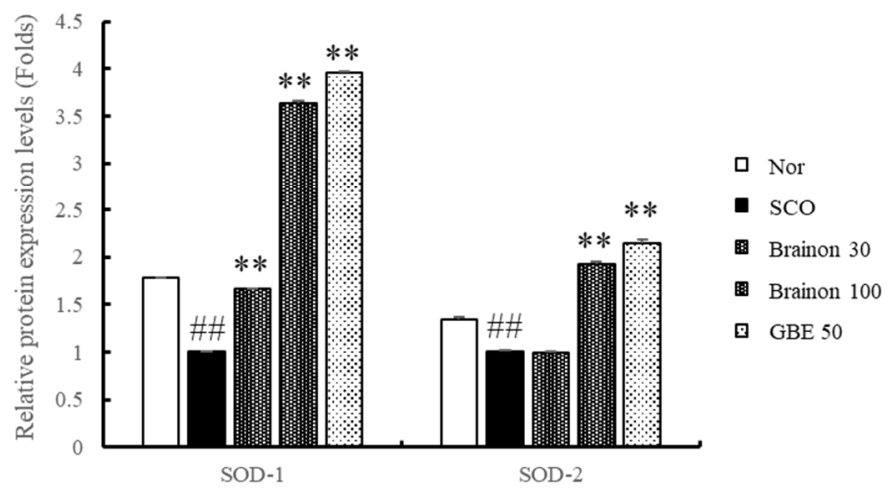

Figure 6. Effects of Brainon on anti-oxidant related protein levels in the hippocampal tissues of memory deficit mice. (A) Superoxide dismutase (SOD)-1, and SOD-2 protein expression were evaluated via western blotting. (B) The protein band density was measured utilizing by the software. Protein was normalized using the GAPDH. Values are represented as means $\pm \operatorname{SEM}(n=3)$. \#\# $p<0.01$ vs. Normal group; ${ }^{* *} p<0.01$ vs. SCO-treated group.

3.7. Brainon Decreases Interleukin (IL)-1 $\beta, I L-6$, and Tumor Necrosis Factor (TNF)- $\alpha$ mRNA Expression in SCO-Induced Hippocampal Tissue

The effects of Brainon on the expression of IL-1 $\beta$, IL-6, and TNF- $\alpha$ mRNA in the hippocampi of SCO-treated mice were confirmed using real-time qPCR (Figure 7). SCO treatment significantly increased expression of IL-1 $\beta$, IL-6, and TNF- $\alpha$ mRNA compared to that in the Normal group $(p<0.01)$. Figure 7 shows that the expression of IL- $1 \beta$ mRNA significantly decreased after treatment with $100 \mathrm{mg} / \mathrm{kg}$ Brainon $(p<0.01)$ and $50 \mathrm{mg} / \mathrm{kg}$ GBE $(p<0.01)$ by $30 \%$ and $18 \%$, respectively, compared to the SCO-injected group. In comparison with the SCO-injected group, expression of IL-6 mRNA was reduced dose dependently after treatment with $30(p<0.05)$ and $100(p<0.01) \mathrm{mg} / \mathrm{kg}$ Brainon by 25\% and $29 \%$, respectively, and even further reduced by $35 \%$ after treatment with $50(p<0.01)$ $\mathrm{mg} / \mathrm{kg}$ GBE. Treatment with $100 \mathrm{mg} / \mathrm{kg}$ Brainon $(p<0.01)$ and $50 \mathrm{mg} / \mathrm{kg} \mathrm{GBE}(p<0.01)$ considerably alleviated TNF- $\alpha$ mRNA expression by $22 \%$ and $28 \%$, respectively, compared to that in the SCO-injected group. 

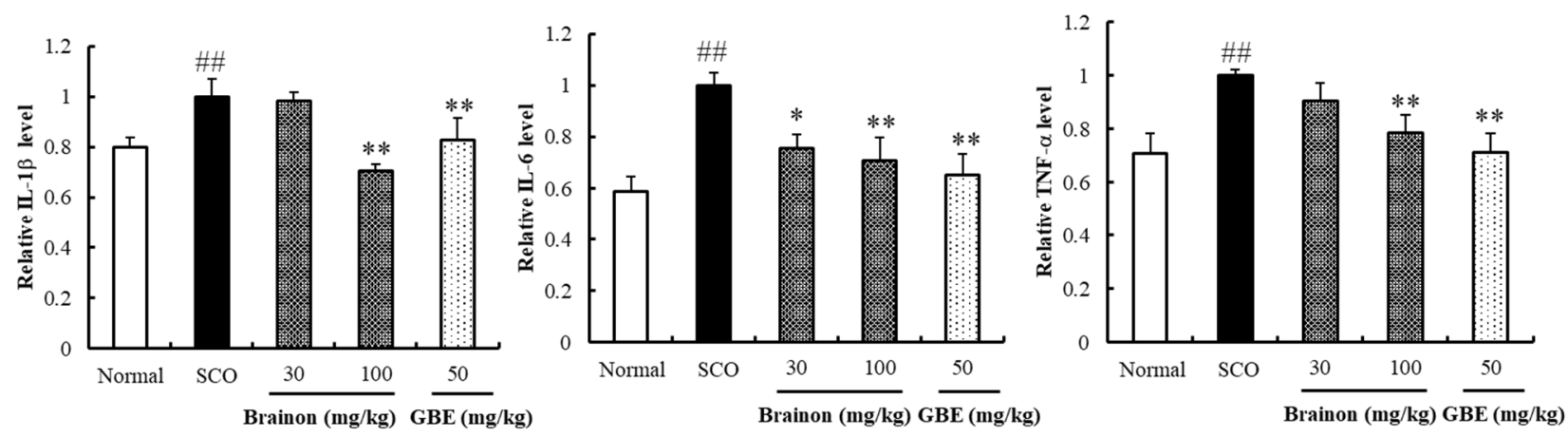

Figure 7. Effects of Brainon on anti-inflammation related mRNA expression in the memory deficit mice hippocampal tissues. Interleukin (IL)-1 $\beta$, IL-6, and tumor factor necrosis (TNF)- $\alpha$ was evaluated by real-time qPCR. The levels of IL-1 $\beta$, IL-6, and TNF- $\alpha$ mRNA were normalized utilizing the glyceraldehyde 3-phosphate dehydrogenase (GAPDH) as control. Values are represented as means $\pm \operatorname{SEM}(n=3)$. \#\# $p<0.01$ vs. Normal group; ${ }^{*} p<0.05$ and ${ }^{* *} p<0.01$ vs. SCO-treated group.

\subsection{Brainon Suppresses Apoptosis-Related Protein Levels in SCO-Induced Hippocampal Tissue}

To demonstrate the effects of Brainon on SCO-induced apoptosis, we examined Bax, Bcl-2, cleaved caspase-9, and cleaved-PARP protein expression in the mouse hippocampus. As shown in Figure 8, SCO injection markedly upregulated protein levels of Bax, cleaved caspase-9, and cleaved-PARP comparison with that in the Normal control group. On the contrary, Bcl-2 protein levels downregulated in the SCO-treated group. Meanwhile, treatment with $30(p<0.01)$ and $100 \mathrm{mg} / \mathrm{kg}$ Brainon $(p<0.01)$, and $50 \mathrm{mg} / \mathrm{kg} \mathrm{GBE}$ $(p<0.01)$ significantly prevented the SCO-caused increase in the expression of Bax and cleaved-PARP proteins. Treatment with $100 \mathrm{mg} / \mathrm{kg}(p<0.01)$ Brainon also decreased the expression of cleaved-caspase 9 proteins but $50 \mathrm{mg} / \mathrm{kg}$ GBE did not reduce cleavedcaspase 9. Furthermore, treatment with $100 \mathrm{mg} / \mathrm{kg}$ Brainon $(p<0.01)$ restored the SCOcaused reduction in $\mathrm{Bcl}-2$ protein expression in the hippocampi.

A

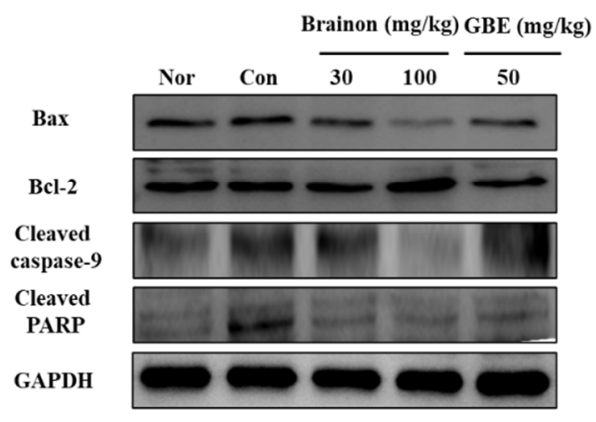

B

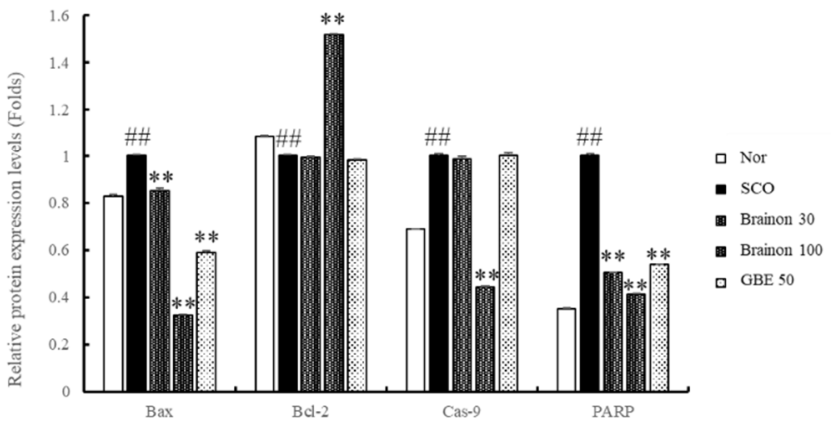

Figure 8. Effects of Brainon on cell death-related protein expression in the memory deficit mice hippocampal tissues. (A) Bcl-2-associated X protein (Bax), B-cell lymphoma 2 (Bcl-2), cleaved caspase-9 and cleaved poly (adenosine diphosphate (ADP)-ribose) polymerase (PARP) protein was analyzed using western blotting. (B) The density of the protein bands was determined utilizing the software. Protein was normalized using the GAPDH. Values are represented as means \pm SEM $(n=3)$. \#\# $p<0.01$ vs. Normal group; ${ }^{* *} p<0.01$ vs. SCO-treated group.

\section{Discussion}

Dementia is a complex condition involving the disruption of cortical function along with adverse effects on memory, reasoning, orientation, learning capacity, and emotional stability. Progressive dementia is associated with $\mathrm{AD}$, a prevalent neurodegenerative disorder, characterized by excessive accumulation of neuritic plaques and neuronal loss, including abnormal tau proteins and $\beta$-amyloid. A depletion of the neurotransmitter, $\mathrm{ACh}$, 
occurs in patients with AD. Degeneration of the cholinergic neurons is also an crucial factor that contributes toward the development of dementia [15].

In this study, mice were tested to a passive avoidance test and an MWM task in a spatial memory trial to assess their learning abilities and memory deficits [6]. SCO treatment significantly decreased cognitive function as reported in a previous study [16]. However, Brainon treatment recovered the decreased step-through latency and reduced escape latency and swim distance in passive avoidance performance and MWM trials, respectively.

ACh establishes synaptic connections between neurons; it plays an important role in the CNS and is related to cognition and memory [17]. ACh is hydrolyzed by AChE. Increased ACh levels resulting from AChE inhibition enhance learning and memory by improving cholinergic deficiency $[15,18]$. Acting as a non-selective muscarinic cholinergic receptor antagonist, $\mathrm{SCO}$ causes cholinergic dysfunction that leads to impaired learning and memory. It is known that $\mathrm{AChE}$ inhibitors antagonize the effects of scopolamine on spatial memory in the radial arm maze [19] in the Morris Water maze and in passive avoidance tests $[20,21]$. This suggests a strong correlation between anti-AChE activity and the ability to oppose these amnestic effects of scopolamine [22]. We administered SCO to mice to induce cholinergic neurodegeneration alongside cognitive deficiency and confirmed the decline in ACh levels and increase in AChE activity [23]. We discovered that Brainon treatment significantly enhanced ACh levels and decreased AChE activity in the hippocampi of SCO-injected mice.

SCO-induced neurodegeneration results in a decrease in cholinergic activity and BDNF as well as the inhibition of phosphorylated CREB expression in the hippocampal tissue [4]. High BDNF expression in the CNS, particularly in the hippocampus, is a neurotrophic factor that modulates the growth and survival of neurons. BDNF enhances synaptic plasticity and regulates memory formation by increasing the activity of enzymes related to ACh synthesis [24]. CREB also leads to neuronal synaptic plasticity through the expression of downstream targets of $\mathrm{Bcl}-2$ and neuroprotective effectiveness against reactive oxygen species (ROS)-caused cell toxicity $[25,26]$. Disturbance of phosphorylated CREB indicates neurodegenerative disorders, such as AD as well as Huntington's and Parkinson's disease $[25,27]$. In this study, we assessed the relevance of the CREB-BDNF signaling mechanism in AD. Brainon upregulated BDNF protein levels as well as phosphorylated CREB protein levels in the hippocampi comparison with those in the SCO-treated group.

ROS induces oxidative stress and is significant in the pathology of AD [9,28]. Excessive oxidative damage induces neuroinflammation and results in neurotoxicity, contributing to clinical symptoms of AD, including cognitive deficits [29,30] Antioxidant enzymes, such as SOD-1 and SOD-2, play a protective role against oxidative stress by catalyzing the conversion of superoxide anions to oxygen and hydrogen peroxide. Results from previous studies show that $\mathrm{ACh}$ exerts a neuroprotective effect against oxidative stress by increasing the expression of SOD, and that ACh levels are positively related with those of SOD [31,32]. In the present study, treatment with Brainon recovered the antioxidant defense system by increasing SOD and ACh levels in the hippocampal tissues of SCO-induced mice.

ROS-caused oxidative stress is considerably correlated with neuroinflammation, which exacerbates neurodegenerative disorders and contributes to the progression of $\mathrm{AD}$. SCO administration upregulated IL- $1 \beta$, IL-6, and TNF- $\alpha$ levels in mouse hippocampi, and these findings were consistent with the results from previous studies [33,34]. However, Brainon suppressed the SCO-induced neuroinflammatory cytokines in the SCO-treated mouse hippocampi. ROS, the primary cause of oxidative stress, is also responsible for the initiation of apoptosis. It promotes the overexpression of the proapoptotic protein, Bax, leading to cell death. The antiapoptotic protein, Bcl-2, which has effects opposite to those of Bax, is regulated by CREB. Bax upregulation and Bcl-2 downregulation promote neuronal cell death by increasing caspase activator release in the hippocampal tissue $[12,35,36]$. Our results suggested that SCO activated Bax, cleaved caspase-9, and cleaved-PARP, while downregulating protein expression of $\mathrm{Bcl}-2$. Moreover, we found that Brainon alleviated 
the overexpression of Bax and the activation of cleaved caspase-9, cleaved-PARP, and on the other hand increased protein expression of Bcl-2 in SCO-treated mice.

To summarize, Brainon was found to have an anti-amnesic effect, which could be regulated by cholinergic activity and the CREB-BDNF signaling pathway, and by virtue of its antioxidant, anti-inflammation, and anti-apoptotic properties.

\section{Conclusions}

In this study, we proved that Brainon effectively restored memory in the SCO-induced mouse model by improving the function of the cholinergic system and CREB-BDNF pathway. Brainon exerted antioxidant effects by inhibiting ROS generation and upregulating the SOD proteins. Decreased ROS levels by Brainon treatment resulted in anti-inflammatory effects by the downregulation of IL-1 $\beta$, IL- 6 , and TNF- $\alpha$, as well as anti-apoptotic effects with decreased protein levels of Bax, cleaved caspase-9, and cleaved-PARP. This study indicated that Brainon is a potential treatment option for patients with neurodegenerative diseases. Moreover, it could potentially be developed as a safe healthcare supplement to improve cognitive disorder and reverse memory loss.

Author Contributions: H.-J.L. performed the experiments and participated in the writing and interpretation of the manuscript. H.-L.K. and D.-Y.L. conducted the data analysis and quality control assessment respectively. D.-R.L. and B.-K.C. conceptualization and discussed the conclusion and edited the manuscript. S.-H.Y. planned and led the project, and contributed the data review, editing and manuscript finalization. All authors have read and agreed to the published version of the manuscript.

Funding: This study was carried out with the support of the 'Cooperative Research Program for Agriculture Science and Technology Development (Project No. PJ013215012020)' Rural Development Administration, Republic of Korea.

Institutional Review Board Statement: The study was conducted according to the guidelines and approved by the Institutional Animal Care and Use committee of ChemOn Inc. (YoungIn, Korea) (Permission number: 2019-05-003).

Informed Consent Statement: Not applicable.

Data Availability Statement: Not applicable.

Acknowledgments: Not applicable.

Conflicts of Interest: Author D.-R.L. is director of research institute of Nutrapharm Tech Co., Ltd. Author B.-K.C. is chief executive officer of Nutrapharm Tech Co., Ltd. The authors declare no conflict of interest.

\section{References}

1. Demirci, K.; Nazıroğlu, M.; Övey, İ.S.; Balaban, H. Selenium attenuates apoptosis, inflammation and oxidative stress in the blood and brain of aged rats with scopolamine-induced dementia. Metab. Brain Dis. 2017, 32, 321-329. [CrossRef] [PubMed]

2. El-Amarasy, S.A.; Abd-Elsalam, R.M.; Ahmed-Farid, O.A. Ameliorative Effect of Silymarin on Scopolamine-induced Dementia in Rats. Open Access Maced. J. Med. Sci. 2018, 17, 1215-1224. [CrossRef]

3. Lee, B.; Sur, B.; Shim, I.; Lee, H.; Hahm, D.H. Phellodendron amurense and Its Major Alkaloid Compound, Berberine Ameliorates Scopolamine-Induced Neuronal Impairment and Memory Dysfunction in Rats. Korean J. Physiol. Pharmacol. 2012, 16, 79-89. [CrossRef]

4. Lee, B.; Sur, B.; Shim, J.; Hahm, D.H.; Lee, H. Acupuncture stimulation improves scopolamine-induced cognitive impairment via activation of cholinergic system and regulation of BDNF and CREB expression in rats. BMC Complement. Altern. Med. 2014, 14, 338. [CrossRef] [PubMed]

5. Lee, B.; Sur, B.; Park, J.; Shin, H.; Kwon, S.; Yeom, M.; Kim, S.J.; Shim, I.; Yin, C.S.; Lee, H.; et al. Fucoidan Ameliorates Scopolamine-induced Neuronal Impairment and Memory Dysfunction in Rats via Activation of Cholinergic System and Regulation of cAMP-response Element-binding Protein and Brain-derived Neurotrophic Factor Expressions. J. Korean Soc. Appl. Biol. Chem. 2012, 55, 711-720. [CrossRef]

6. Shabani, S.; Mirshekar, M.A. Diosmin is neuroprotective in a rat model of scopolamine-induced cognitive impairment. Biomed. Pharmacother. 2018, 108, 1376-1383. [CrossRef] 
7. Lee, J.S.; Kim, H.G.; Lee, H.W.; Han, J.M.; Lee, S.K.; Kim, D.W.; Saravanakumar, A.; Son, C.G. Hippocampal memory enhancing activity of pine needle extract against scopolamine-induced amnesia in a mouse model. Sci. Rep. 2015, 5, 9651. [CrossRef]

8. Karthivashan, G.; Park, S.Y.; Kweon, M.H.; Kim, J.; Haque, M.E.; Cho, D.Y.; Kim, I.S.; Cho, E.A.; Ganesan, P.; Choi, D.K. Ameliorative potential of desalted Salicornia europaea L. extract in multifaceted Alzheimer's-like scopolamine-induced amnesic mice model. Sci. Rep. 2018, 8, 7174. [CrossRef]

9. Budzynska, B.; Czubara, A.B.; Slomka, M.K.; Wozniak, K.S.; Michalak, A.; Musik, I.; Biala, G. Effects of imperatorin on scopolamine-induced cognitive impairment and oxidative stress in mice. Psychopharmacology 2015, 232, 931-942. [CrossRef]

10. Kim, J.K.; Kim, Y.H.; Lee, H.H.; Lim, S.S.; Park, K.W. Effect of Scrophularia buergeriana Extract on the Degranulation of Mast Cells and Ear Swelling Induced by Dinitrofluorobenzene in Mice. Inflammation 2011, 35, 183-191. [CrossRef]

11. Lee, H.J.; Spandidos, D.A.; Tsatsakis, A.; Margina, D.; Izotov, B.N.; Yang, S.H. Neuroprotective effects of Scrophularia buergeriana extract against glutamate-induced toxicity in SH-SY5Y cells. Int. J. Mol. Med. 2019, 43, 2144-2152. [CrossRef] [PubMed]

12. Lee, H.J.; Lee, D.Y.; Kim, H.L.; Yang, S.H. Scrophularia buergeriana Extract Improves Memory Impairment via Inhibition of the Apoptosis Pathway in the Mouse Hippocampus. Appl. Sci. 2020, 10, 7987. [CrossRef]

13. DeFeudis, F.V.; Drieu, K. "Stress-alleviating" and "vigilance-enhancing" actions of Ginkgo biloba extract (EGb 761). Drug Dev. Res. 2004, 62, 1-25. [CrossRef]

14. Tang, F.; Nag, S.; Shiu, S.Y.W.; Pang, S.F. The effects of melatonin and Ginkgo biloba extract on memory loss and choline acetyltransferase activities in the brain of rats infused intracerebroventricularly with $\beta$-amyloid 1-40. Life Sci. 2002, 71, $2625-2631$. [CrossRef]

15. Puri, A.; Srivastava, P.; Pandey, P.; Yadav, R.S.; Bhatt, P.C. Scopolamine induced behavioral and biochemical modifications and protective effect of Celastrus paniculatous and Angelica glauca in rats. Int. J. Nutr. Pharmacol. Neurol. Dis. 2014, 4, 158-163. [CrossRef]

16. Ko, Y.H.; Kwon, S.H.; Lee, S.Y.; Jang, C.G. Isoorientin improves scopolamine-induced cognitive impairments by restoring the cholinergic system, antioxidant defense, and p-CREB/BDNF signaling in the hippocampus and frontal cortex. Arch. Pharm. Res. 2019, 42, 722-731. [CrossRef]

17. Lian, W.; Fang, J.; Xu, L.; Zhou, W.; Kang, D.; Xiong, W.; Jia, H.; Liu, A.L.; Du, G.H. DL0410 Ameliorates Memory and Cognitive Impairments Induced by Scopolamine via Increasing Cholinergic Neurotransmission in Mice. Molecules 2017, 22, 410. [CrossRef]

18. Kim, D.E.; Han, D.Y.; Kim, S.H.; Chung, D.K. Anti-amnesic and Antioxidant Effect of YeongkyekamjotanggayonggoImoryo Aqueous Extracts on Scopolamine-induced Memory Impairment in Mice. J. Orient. Neuropsychiatry 2018, 29, 121-134. [CrossRef]

19. Braida, D.; Paladini, E.; Griffini, P.; Lamperti, M.; Maggi, A.; Sala, M. An inverted U-shaped curve for heptylphysostigmine on radial maze performance in rats: Comparison with other cholinesterase inhibitors. Eur. J. Pharmacol. 1996, 302, 13-20. [CrossRef]

20. Bejar, C.; Wang, R.H.; Weinstock, M. Effect of rivastigmine on scopolamine-induced memory impairment in rats. Eur. J. Pharmacol. 1999, 383, 231-240. [CrossRef]

21. Dawson, G.R.; Bentley, G.; Draper, F.; Rycroft, W.; Iversen, S.D.; Pagella, P.G. The behavioral effects of heptyl physostigmine, a new cholinesterase inhibitor, in tests of long-term and working memory in rodents. Pharmacol. Biochem. Behav. 1991, 39, 865-871. [CrossRef]

22. Kang, S.Y.; Lee, K.Y.; Park, M.J.; Kim, Y.C.; Markelonis, G.J.; Oh, T.H.; Kim, Y.C. Decursin from Angelica gigas mitigates amnesia induced by scopolamine in mice. Neurobiol. Learn. Mem. 2003, 79, 11-18. [CrossRef]

23. Bhuvanendran, S.; Kumari, Y.; Othman, L.; Shaikh, M.F. Amelioration of Cognitive Deficit by Embelin in a Scopolamine-Induced Alzheimer's Disease-Like Condition in a Rat Model. Front. Pharmacol. 2018, 25, 665. [CrossRef] [PubMed]

24. Jegal, K.H.; Park, S.J.; Kim, C.Y.; Park, J.H.; Jang, J.H. Effect of Poria Cocos on the Scopolamine-induced Memory Impairment and Its Underlying Molecular Mechanism. Korean J. Orient. Physiol. Pathol. 2010, 24, 228-235.

25. Mantamadiotis, T.; Lemberger, T.; Bleckmann, S.C.; Kern, B.; Kretz, O.; Villabla, A.M.; Tronche, F.; Kellendonk, C.; Gau, D.; Kapfhammer, J.; et al. Disruption of CREB function in brain leads to neurodegeneration. Nat. Genet. 2002, 31, 47-54. [CrossRef] [PubMed]

26. Li, Q.; Zhao, H.F.; Zhang, Z.F.; Liu, Z.G.; Pei, X.R.; Wang, J.B.; Cai, M.Y.; Li, Y. Long-term administration of green tea catechins prevents age-related spatial learning and memory decline in C57BL/6J mice by regulating hippocampal cyclic amp-response element binding protein signaling cascade. Neuroscience 2009, 159, 1208-1215. [CrossRef] [PubMed]

27. Ravichandran, V.A.; Kim, M.; Han, S.K.; Cha, Y.S. Stachys sieboldii Extract Supplementation Attenuates Memory Deficits by Modulating BDNF-CREB and Its Downstream Molecules, in Animal Models of Memory Impairment. Nutrients 2018, 10, 917. [CrossRef]

28. Akesenov, M.Y.; Markesbery, W.R. Changes in thiol content and expression of glutathione redox system genes in the hippocampus and cerebellum in Alzheimer's disease. Neurosci. Lett. 2001, 302, 141-145. [CrossRef]

29. Bartus, R.T. On neurodegenerative diseases, models, and treatment strategies: Lessons learned and lessons forgotten a generation following the cholinergic hypothesis. Exp. Neurol. 2000, 163, 495-529. [CrossRef]

30. Bonda, D.J.; Wang, X.; Perry, G.; Nunomura, A.; Tabaton, M.; Zhu, X.; Smith, M.A. Oxidative stress in Alzheimer's disease: A possibility for prevention. Neuropharmacology 2010, 59, 290-294. [CrossRef]

31. Zhang, W.; Bai, M.; Hao, J.H.; Mao, N.; Su, C.; Miao, J.; Li, Z. Early memory deficits precede plaque deposition in APPswe/Ps1dE9 mice: Involvement of oxidative stress and cholinergic dysfunction. Free Radic. Biol. Med. 2012, 52, 1443-1452. [CrossRef] [PubMed] 
32. Frinchi, M.; Nuzzo, D.; Scaduto, P.; Carlo, M.D.; Massenti, M.F.; Belluardo, N.; Mudò, G. Anti-inflammatory and antioxidant effects of muscarinic acetylcholine receptor (mAChR) activation in the rat hippocampus. Sci. Rep. 2019, 9, 14233. [CrossRef]

33. Guo, C.; Shen, J.; Meng, Z.; Yang, X.; Li, E. Neuroprotective effects of polygalacic acid on scopolamine-induced memory deficits in mice. Phytomedicine 2016, 23, 149-155. [CrossRef] [PubMed]

34. Iqbal, S.; Shah, F.A.; Naeem, K.; Nadeem, H.; Sarwar, S.; Ashraf, Z.; Imran, M.; Khan, T.; Anwar, Y.; Li, S. Succinamide Derivatives Ameliorate Neuroinflammation and Oxidative Stress in Scopolamine-Induced Neurodegeneration. Biomolecules 2020, 10, 443. [CrossRef] [PubMed]

35. Muhammad, T.; Ali, T.; Ikram, M.; Khan, A.; Alam, S.I.; Kim, M.O. Melatonin Rescue Oxidative Stress-Mediated Neuroinflammation/Neurodegeneration and Memory Impairment in Scopolamine-Induced Amnesia Mice Model. J. Neuroimmune Pharmacol. 2019, 14, 278-294. [CrossRef]

36. Puangmalai, N.; Thangnipon, W.; Ampornkul, R.S.; Suwanna, N.; Tuchinda, P.; Nobathian, S. Neuroprotection of Nbenzylcinnamide on scopolamine-induced cholinergic dysfunction in human SH-SY5Y neuroblastoma cells. Neural Regen. Res. 2017, 12, 1492-1498. [CrossRef] 